\title{
2-methyl-3-buten-2-ol: A Pheromone Component of Conifer Bark Beetles Found in the Bark of Nonhost Deciduous Trees
}

\author{
Qing-He Zhang, ${ }^{1,2}$ Fredrik Schlyter, ${ }^{1}$ and Göran Birgersson ${ }^{1}$ \\ ${ }^{1}$ Chemical Ecology, Department of Plant Protection Biology, Swedish University of Agricultural Sciences, P.O. Box 102, 23053 Alnarp, \\ Sweden \\ ${ }^{2}$ RÆD Department, Sterling International, Inc., 3808 N. Sullivan Road Building 16, Spokane, WA 99216, USA
}

Correspondence should be addressed to Qing-He Zhang, qing-he@rescue.com

Received 30 December 2011; Accepted 9 February 2012

Academic Editor: John A. Byers

Copyright (๑) 2012 Qing-He Zhang et al. This is an open access article distributed under the Creative Commons Attribution License, which permits unrestricted use, distribution, and reproduction in any medium, provided the original work is properly cited.

\begin{abstract}
Volatiles from bark of aspen, Populus tremula L. and two species of birch: silver birch (Betula pendula Roth.) and common birch (B. pubescens Ehrh.), were collected by direct solvent extraction and aeration of both newly cut bark chips and undamaged stems in June 1998 and subjected to GC-MS analysis. The results showed the presence of 2-methyl-3-buten-2-ol (MB), one of the two principal aggregation pheromone components of the spruce bark beetle, Ips typographus, in bark extraction samples of all the three deciduous tree species tested. In addition, one more oxygenated hemiterpene, 3-methyl-3-buten-2-one, and (E)-3-penten-2ol were also found in the bark extracts. Only trace amounts of MB were detected in some aeration samples of the fresh bark chips, and no MB was found from the aeration samples of undamaged stems at detectable levels. The occurrence of this compound was also confirmed in the bark of four exotic birch species: B. albosinensis Schneid., B. ermanii Cham., B. jacquemontii Spach, and B. maximowicziana Regel, but not yet in the European pines/spruces and the common yeasts. Our results raise major questions regarding the evolution, the tropospheric chemistry, and the ecological role of this hemiterpene alcohol. They also suggest that comparative studies on the biosynthetic pathways for $\mathrm{MB}$ in different sources would be of considerably evolutionary interest.
\end{abstract}

\section{Introduction}

Aspen, Populus tremula L. and two birch species, silver birch (Betula pendula Roth.) and common birch (B. pubescens Ehrh.), are the most common deciduous trees in Norway spruce forests of Scandinavia [1]. Studies showed that volatiles from leaves and bark of nonhost aspen/birch trees strongly inhibit pheromone attraction in spruce bark beetles, Ips typographus L. and Pityogenes chalcographus L. [2,3]. In order to determine what kind of volatiles are responsible for the inhibition effect, volatiles from these nonhost trees were collected by headspace aerations and solvent extraction and analyzed by GC-MS $[1,4,5]$. Further electrophysiological and field bioassay studies showed that green leaf alcohols (GLVs) from leaves and bark and some specific compounds like trans-conophthorin, from bark of the nonhost deciduous trees, disrupt the secondary attraction response of sympatric coniferophagous bark beetles $[4,5]$. Such inhibitory effects by angiosperm nonhost volatiles have been shown on many other conifer-inhabiting bark beetles throughout the world [3]. In the present paper, we report our finding of 2-methyl3-buten-2-ol (here abbreviated as MB [6], while in atmospheric chemistry often as $\mathrm{MBO}$ ), one of the principal aggregation pheromone components of I. typographus, in the bark of its nonhost trees P. tremula, B. pendula, and B. pubescens, which poses questions regarding the evolution and ecological role of this semiochemical in the natural habitat.

\section{Materials and Methods}

Volatiles from the nonhost bark were collected by direct extraction with diethyl ether and by aerations of both newly cut bark chips and undamaged stems in June 1998, Asa, Småland, Sweden. One $\mathrm{cm}^{2}$ of bark cut into $2 \times 5 \mathrm{~mm}$ pieces taken at $1.5 \mathrm{~m}$ height of standing trees from each species was extracted in $1 \mathrm{~mL}$ of diethyl ether. Fresh bark chips (size: 3 $\times 6 \mathrm{~cm}$, with total area of $\mathrm{ca} .1000 \mathrm{~cm}^{2}$ ) from each individual 
tree at breast height were aerated in the laboratory within 15$30 \mathrm{~min}$ after bark sampling. They were enclosed in a plasticcooking bag $(35 \times 43 \mathrm{~cm})$ with an activated charcoal filter tube at the air inlet. The volatiles in the bag were trapped on Porapak Q (30 mg, mesh 50-80 (Supelco), in Teflon tube: ID $3 \mathrm{~mm} \times 35 \mathrm{~mm}$ ) for $2 \mathrm{~h}$ at airflow rate of $300 \mathrm{~mL} / \mathrm{min}$ and recovered by extraction with diethyl ether [1]. The same aeration setup was also used for the volatile collection from the undamaged stems at $1.3-1.7 \mathrm{~m}$ height for $1.5 \mathrm{~h}$ with battery-operated pumps. Air temperatures inside and outside of sampling bags were recorded during the aerations with a Min-Max reading thermometer. Additional fresh bark extraction samples of four exotic birch species, $B$. albosinensis Schneid., B. ermanii Cham., B. jacquemontii Spach, and B. maximowicziana Regel, using the same sampling approach as described previously for the three native Scandinavian species were taken from the Alnarp Botanical Garden, Skåne, Sweden in February 1999. All extracts were kept at $-20^{\circ} \mathrm{C}$ before the GC-MS analysis. After collection, the bark samples were dried at $65^{\circ} \mathrm{C}$ for $72 \mathrm{~h}$ and weighed. The detailed information about the bark sampling is shown in Table 1 .

The chemical analyses were made by a combined HP 5890 series II gas chromatography and HP 5972 mass selective detector (GC-MSD). The GC was equipped with a $25 \mathrm{~m} \times 0.25 \mathrm{~mm} \times 0.30 \mu \mathrm{m}$ fused silica column, coated with CP-Wax no. 58 (FFAP CB) (Agilent Technologies). All samples were injected by a HP 7673 autoinjector $(2 \mu \mathrm{L}$ each). Helium was used as the carrier gas at an electronically controlled constant flow of $31 \mathrm{~cm} / \mathrm{s}$. The injector temperature was $200^{\circ} \mathrm{C}$, and oven temperature was at $30^{\circ} \mathrm{C}$ for the first $3 \mathrm{~min}$, then programmed to $200^{\circ} \mathrm{C}$ at $10^{\circ} \mathrm{C} / \mathrm{min}$, where it remained for $2 \mathrm{~min}$.

Volatiles were identified by comparison of the retention indices and mass spectra with those of authentic compounds, with computerized data library, NBS75K, and with custom produced library (KE1995). Absolute amounts were obtained by comparison to the internal standard, the stabilizer, butylated hydroxytoluene (BHT) of diethyl ether.

\section{Results}

GC-MS analyses of bark solvent extracts clearly showed the presence of 2-methyl-3-buten-2-ol (MB) in the bark of all the three native Scandinavian deciduous tree species tested (Figure 1). This identification was proven by comparison of retention time and mass spectrum to the authentic compound and computer data libraries (NBS75K and KE1995) (Figure 1). The amounts of $\mathrm{MB}$ in the extracts were estimated ca $4.5,2.5$, and $10.7 \mu \mathrm{g} / \mathrm{g} \mathrm{dw}$, for B. pendula, B. pubescens and $P$. tremula, respectively (Table 2 ). In addition to the $\mathrm{MB}$, one more oxygenated hemiterpene, 3-methyl-3-buten2-one, and (E)-3-penten-2-ol were identified in the bark extracts, with their average amounts being lower than that of MB (Table 2). The occurrence of MB as a minor component was also confirmed in the bark samples of four exotic birch species: B. albosinensis, B. ermanii, B. jacquemontii, and $B$. maximowicziana by GC-MS.

GC-MS analyses of some aeration samples of the fresh bark chips did also indicate the presence of $\mathrm{MB}$, but only in trace amounts which might be due to the major breakthrough of this highly volatile alcohol through the Porapak Q trap [7]. No MB was found in the aeration samples of undamaged stems at detectable levels.

\section{Discussion}

4.1. Insect Sources. MB was first identified as one of the principal aggregation pheromone components of spruce bark beetle, Ips typographus [8], and was also observed in emissions from the entrance holes made by this species on the trunks of both live [7] and cut [9] spruce trees [10], with emission rates per bore hole being significantly larger than the average content of hindgut. It has been reported as a pheromone component or male-specific compound of several other conifer bark beetles in Eurasia, Ips (Orthotomicus) erosus Woll. [11], I. nitidus Eggers [12], I. shangrila Cognato and Sun [13], Pteleobius vittatus (F.) [14], and Pityogenes spp. [15]. MB was found to be produced by females of Ips amitinus (Eichhoff) as well and seemed to be inhibitive [16]. It is reportedly an alarm pheromone of the European hornet, Vespa crabro L. [17].

4.2. Plant Sources. This is the first report on the presence of $\mathrm{MB}$ in bark of deciduous trees. In addition to the three major native angiosperm deciduous tree species ( $P$. tremula, $B$. pendula, and $B$. pubescens), MB was also detected in bark samples (taken in February) of several exotic birch species, including B. albosinensis, B. ermanii, B. jacquemontii and B. maximowicziana. Thus, its natural occurrence in plants might be much more common than we ever realized. In fact, the emission of this isoprene alcohol from plants had been observed before; the orchid Aerides lawrenceae produces $\mathrm{MB}$ [18]. Interestingly, $\mathrm{MB}$ is also a hop constituent with sedative hypnotic activity [19] and formed from humulones and lupulones by reaction with $\mathrm{OH}$ radicals in the presence of atmospheric oxygen [20]. Further study suggested that the same reaction with $\mathrm{OH}$ radicals may occur in vivo. For instance, it induced the murine cytochrome P4503A and ethylmorphine $\mathrm{N}$-demethylation (a functional marker for $\mathrm{P} 4503 \mathrm{~A})$ in mice [21]. Both 2-methyl-3-buten-2-ol (MB) and 3-methyl-3-buten-2-one are parts of volatile composition from the headspace of five lima bean plants infested with two-spotted spider mites (Tetranychus urticae Koch) [22]. $\mathrm{MB}$ is also a fragrance ingredient used in cosmetics, fine fragrances, shampoos, toilet soaps, and other toiletries as well as in noncosmetic products such as household cleaners and detergents [23].

Zimmerman et al. (1991) noted the presence of MB in samples taken from enclosures placed around branches of Loblolly pine (Pinus taeda L.) [24]. Goldan et al. (1993) characterized the trace gas composition of ambient air in a small clearing in a predominantly lodgepole pine forest with a significant admixture of aspen and occasional Colorado blue spruce (3050 m elevation) in Colorado in June 1991 [25]. They found $\mathrm{MB}$ to be the dominant volatile organic compound (VOC), with a concentration 4-7 times higher than that of isoprene. Based on the fact that diurnal changes in 


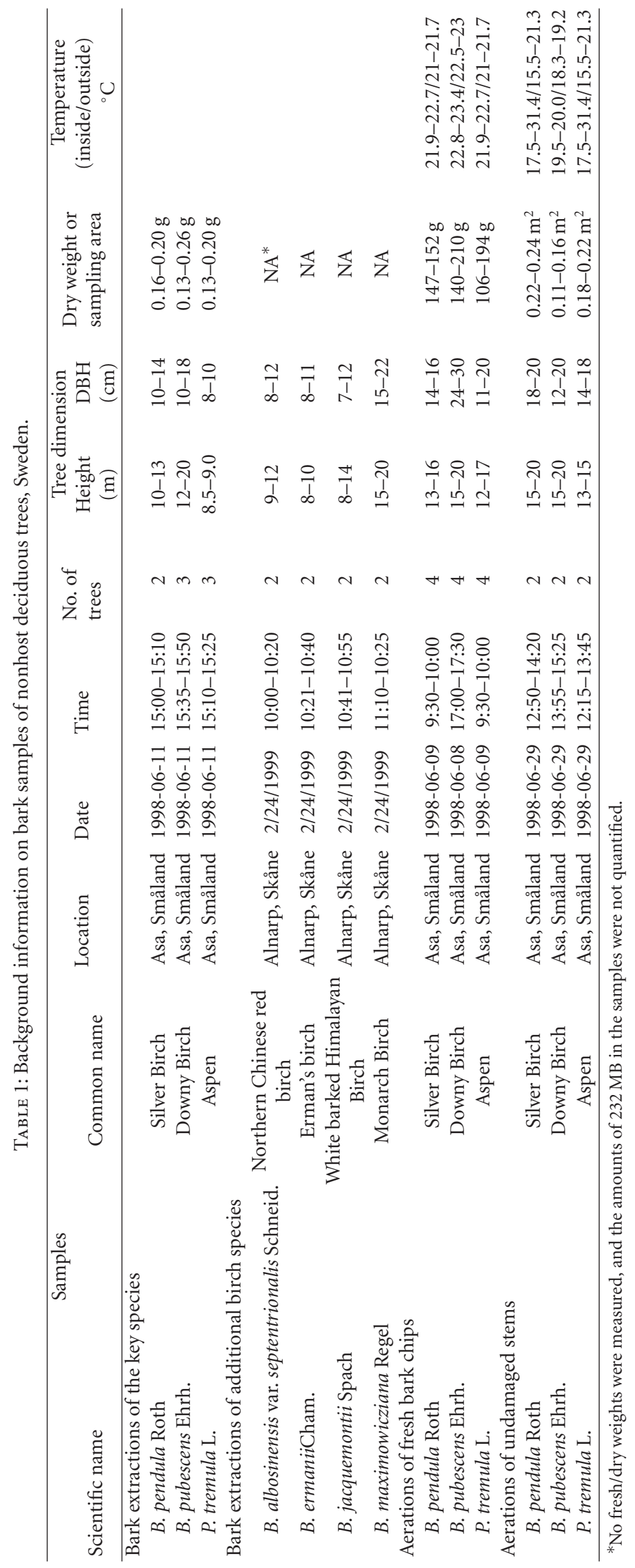




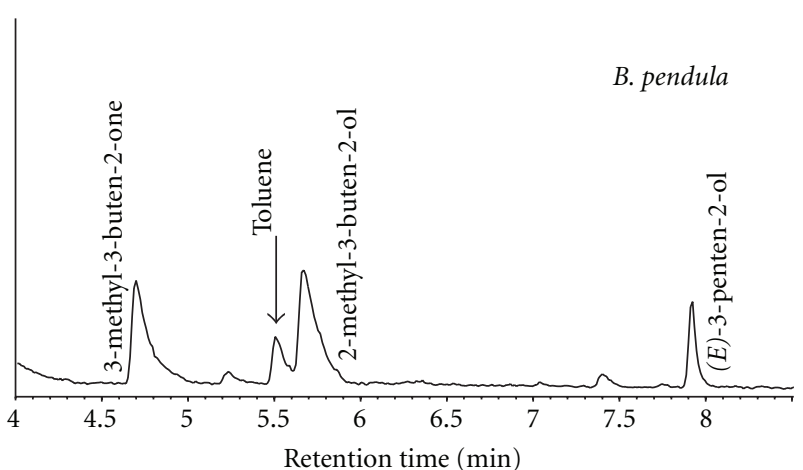

(a)

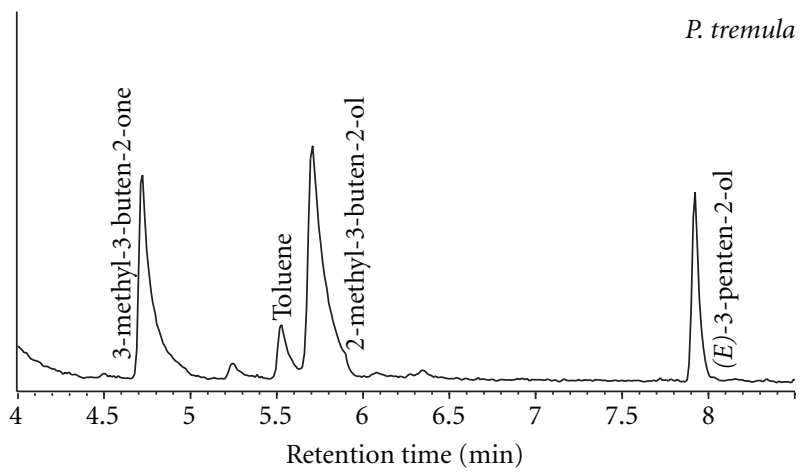

(c)

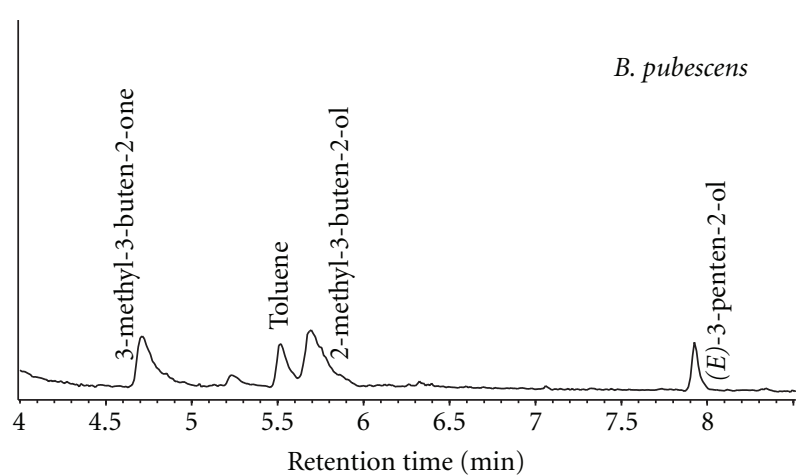

(b)

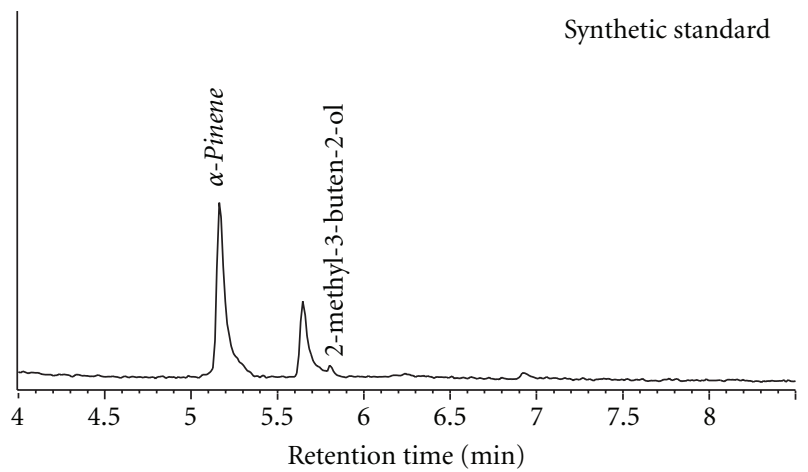

(d)

Figure 1: Gas chromatograms from bark extracts of B. pendula, B. pubescens, and P. tremula, and synthetic standard of 2-methyl-3-buten2-ol (MB).

TABle 2: Amounts of oxygenated hemiterpenes and (E)-3-penten2-ol present in the bark extracts of deciduous trees, Asa, Sweden, June 11, 1998.

\begin{tabular}{lccc}
\hline \multirow{2}{*}{ Compounds } & \multicolumn{4}{c}{ Mean $\pm \mathrm{SD}(\mu \mathrm{g} / \mathrm{g}$ DW bark $)$} \\
& $\begin{array}{c}\text { B. pendula } \\
(n=2)\end{array}$ & $\begin{array}{c}\text { B. pubescens } \\
(n=3)\end{array}$ & $\begin{array}{c}\text { P. tremula } \\
(n=3)\end{array}$ \\
\hline 2-methyl-3-buten-2-ol (MB) & $4.53 \pm 1.37$ & $2.51 \pm 2.80$ & $10.68 \pm 5.63$ \\
3-methyl-3-buten-2-one & $3.83 \pm 1.13$ & $1.66 \pm 2.06$ & $7.42 \pm 4.33$ \\
(E)-3-penten-2-ol & $1.37 \pm 0.46$ & $0.61 \pm 0.81$ & $4.04 \pm 2.02$ \\
\hline
\end{tabular}

ambient MB concentrations were very similar to those of isoprene, with known biogenic sources, and on the fact that $\mathrm{MB}$ concentrations did not correlate well with those of benzene, an indicator of anthropogenic source, they concluded that there was likely to be a large local biogenic source of $\mathrm{MB}$, probably the lodgepole pine forest. Harley et al. (1998) successfully detected and measured the emission of $\mathrm{MB}$ from needles of several North American pine species, confirming $\mathrm{MB}$ as a biogenic VOC (BVOC) [26]. MB emissions from Pinus ponderosa were absent in the dark and strongly dependent on incident light, behaving similarly to net photosynthesis. The fact that $\mathrm{MB}$ emissions rapidly fall to near zero in darkness suggested that MB is being emitted immediately upon production, rather than stored in any specialized structures of pine needles. Their further screening study on
34 species of pines for $\mathrm{MB}$ emission in California showed that 11 species exhibited high emissions of $\mathrm{MB}(>5 \mu \mathrm{g} \mathrm{C} / \mathrm{g} / \mathrm{h})$, and 6 emitted small but detectable amounts. All the emitting species are of North American origin, and most are restricted to western North America. Their results from both intact and severed branches indicated that $\mathrm{MB}$ emissions from pines may constitute a significant source of reactive carbon and a significant source to the atmosphere of acetone, a product of $\mathrm{MB}$ oxidation [26]. Interestingly, we find no $\mathrm{MB}$ records from European pines, and MB is not detected, based on its characteristic base ion $m / z=71$, in the host tree Picea abies L. neither from bark extracts (C. Schiebe, unpubl.) nor emitted from foliage (M. Binyameen, unpubl.).

4.3. Microbial Sources. A plethora of short-chained BVOC is produced by yeasts and other microorganisms, including methyl butenol isomers [27, 28]. Somewhat surprisingly, the insect- and plant-produced 2-methyl-3-buten-2-ol is not reported in the microbial-related literatures, and is not found among VOCs analyzed with GC-MS from different types of cultured yeasts (M. Proffit, unpubl results).

4.4. Atmospheric Chemistry. Following the observation of $\mathrm{MB}$ emission in pine forest by Goldan et al. (1993) [25], several studies on the atmospheric chemistry of this BVOC alcohol have been actively carried out [29-35]. Harley et al. (1998) claimed that the major photochemical sink for MB 
during daylight hours is assumed to be with $\mathrm{OH}^{-}$[26]. The rate coefficients with similar values for the $\mathrm{OH}^{-}$reaction with MB were reported by Rudich et al. (1995) and Ferronato et al. (1998), which suggested a relatively short atmospheric lifetime of ca. 2 hours [30,34]. However, given typical atmospheric values of $\mathrm{O}_{3}$ and $\mathrm{NO}_{3}$, the rate constants for $\mathrm{MB}$ reaction with $\mathrm{O}_{3}[32]$ or with $\mathrm{NO}_{3}[33,34]$ imply significantly longer $\mathrm{MB}$ lifetimes with respect to these destruction processes. Further reaction chamber experiments $[29,30]$ indicate that the $\mathrm{MB}-\mathrm{OH}$ reaction leads to the production of acetone, glycol aldehyde, formaldehyde, and presumably 2-hydroxy-2-methylpropanal. The reaction with $\mathrm{O}_{3}$ appears to yield the same major products, though in different proportions [29, 32]. Recently, Chan et al. (2009) suggested that photooxidation of $\mathrm{MB}$ might be a potential but minor source of secondary organic aerosol (SOA) [35]. Despite its structural similarity to isoprene, photooxidation of $\mathrm{MB}$ is not expected to make a significant contribution to SOA formation [35].

By using a model considering landscape average emission potential $\left(\mu \mathrm{g} \mathrm{C} \mathrm{g}^{-1} \mathrm{~h}^{-1}\right)$, total foliar density $\left(\mathrm{g} \mathrm{m}^{-2}\right)$ (estimated by the available data on forest biomass and species composition), and emission activity factor, Harley et al. (1998) were able to compare the ambient concentrations of MB observed by Goldan et al. (1993) with their own enclosure rates of $\mathrm{MB}$ emission and found a reasonable agreement $[25,26]$. Recent estimate of global MB emission is about $9.6 \mathrm{Tg}$ per year $[36,37]$.

4.5. Potential Semiochemical Functions. MB seems to have multiple functions, including semiochemical, flavor, and pharmacological roles, and strong impact on atmospheric chemistry, which are dependent on its sources. The role of $\mathrm{MB}$ in the semiochemical system of I. typographus has been intensively studied. On the basis of dose-response curves from electroantennograms (EAGs), Dickens (1981) suggested that $\mathrm{MB}$ might act as a close-range/landing substance as it had a higher threshold ( $100 \mu \mathrm{g}$ on filter paper) and very steep dose-response profile [38]. By using specially designed trap groups, Schlyter et al.(1987) clearly showed that $\mathrm{MB}$ does act as a close-range landing (or entering of trap holes) stimulus in the field [39]. However, our combined gas chromatographic-electroantennographic detection (GCEAD) analysis of the bark extract samples of these three tree species showed no antennal responses by I. typographus to the existing MB (Zhang et al. unpubl.). It is mainly due to the fact that the amounts of $\mathrm{MB}$ in the extracts are much lower than the response threshold of I. typographus [38]. Furthermore, no $\mathrm{MB}$ was detected in the aeration samples of the undamaged stems, which might be caused by either the breakthrough of this compound through the Porapak Q trap or the minor amounts of release. Thus, the amounts of MB produced by the bark of nonhost birch or aspen, or emitted from the undamaged stems if any, most probably have no significant impact on the host selection behavior of I. typographus in the natural habitat. Goldan et al. (1993) doubted the source of MB from I. typographus and speculated an extra-insect source from host spruce trees [25]. In contrast, our GC-MS analyses of aeration samples of bark chips and cut branches with fresh needles of Norway spruce, Picea abies, did not find any MB at detectable levels [1]. In fact, no MB emitting trees had been discovered in Europe where the two bark beetles (I. typographus and Ips (Orthotomicus) erosus) use MB as parts of their pheromone systems prior to our current study.

Inclusion of $\mathrm{MB}$ in a trap consisting of a mixture of pheromone attractants for the spruce bark beetle, Dendroctonus rufipennis, was shown to reduce the number of $D$. rufipennis trapped, suggesting a possible antiattractant role of this alcohol [40]. However, MB exhibited no repellent properties when tested alone nor did it appear to have any effect on the aggregation response of two North American conifer bark beetles (Ips paraconfusus and Dendroctonus brevicomis) and their predators (Trogositidae and Cleridae) to their pheromones [41].

4.6. Biosynthesis. A biosynthetic study by Lanne et al. (1989), using radiolabeled precursors, clearly showed that $\mathrm{MB}$ is produced de novo by I. typographus through the mevalonic pathway [9]. The biosynthetic pathway in other insects (Ips (Orthotomicus) erosus, I. nitidus and I. shangrila, and Vespa crabro) and the Eurasian angiosperm trees (bark of birch and aspen) still remains unknown. However, the gene for MB synthase was recently identified from Pinus sabiniana, the MB producing pine species, and the protein encoded was functionally characterized by Gray et al. (2011) [42]. MB synthase is a bifunctional enzyme which produces both $\mathrm{MB}$ and isoprene in a ratio of ca. 90:1 [42] via dimethylallyl diphosphate (DMADP) [43]. Another oxygenated hemiterpene, 3methyl-3-buten-2-one, was also found constantly from our bark extracts. It is not clear if this oxygenated hemiterpene is involved in the biosynthetic pathway of MB. Our results raise major questions regarding the evolution, tropospheric chemistry, and ecological role of this short, branched alcohol. They also suggest that comparative studies on the biosynthetic pathways for $\mathrm{MB}$ in different natural sources would be of considerable evolutionary interest.

\section{Acknowledgments}

The authors thank their younger colleagues at Chemical Ecology, Alnarp, for sharing their unpublished GC-MS results from Norway spruce (C. Schiebe, M. Binyameen) and yeasts (Dr. M. Proffit), respectively. Their data collection was supported by Grants from the Swedish Council for Forestry and Agricultural Research (SJFR, no. 23.0521/96 and no.24.0293/98) and an EU-INCO project ("TATRY", CT 980151). F. Schlyter and G. Birgersson are supported by the Linnaeus program "Insect Chemical Ecology, Ethology and Evolution” ( $\left.\mathrm{ICE}^{3}\right)$.

\section{References}

[1] Q. H. E. Zhang, G. Birgersson, J. Zhu, C. Löfstedt, J. Löfqvist, and F. Schlyter, "Leaf volatiles from nonhost deciduous trees: variation by tree species, season and temperature, and electrophysiological activity in Ips typographus," Journal of Chemical Ecology, vol. 25, no. 8, pp. 1923-1943, 1999. 
[2] J. A. Byers, Q. H. Zhang, F. Schlyter, and G. Birgersson, "Volatiles from nonhost birch trees inhibit pheromone response in spruce bark beetles," Naturwissenschaften, vol. 85, no. 11, pp. 557-561, 1998.

[3] Q. H. Zhang and F. Schlyter, "Olfactory recognition and behavioural avoidance of angiosperm nonhost volatiles by coniferinhabiting bark beetles," Agricultural and Forest Entomology, vol. 6, no. 1, pp. 1-19, 2004.

[4] Q. H. Zhang, F. Schlyter, and P. Anderson, "Green leaf volatiles interrupt pheromone response of spruce bark beetle, Ips typographus," Journal of Chemical Ecology, vol. 25, no. 12, pp. 28472861, 1999.

[5] Q. H. Zhang, F. Schlyter, and G. Birgersson, "Bark volatiles from nonhost angiosperm trees of spruce bark beetle, Ips typographus (L.) (Coleoptera: Scolytidae): chemical and electrophysiological analysis," Chemoecology, vol. 10, no. 2, pp. 69-80, 2000.

[6] G. Birgersson, F. Schlyter, J. Löfqvist, and G. Bergström, "Quantitative variation of pheromone components in the spruce bark beetle Ips typographus from different attack phases," Journal of Chemical Ecology, vol. 10, no. 7, pp. 1029-1055, 1984.

[7] G. Birgersson and G. Bergström, "Volatiles released from individual spruce bark beetle entrance holes quantitative variations during the first week of attack," Journal of Chemical Ecology, vol. 15, no. 10, pp. 2465-2483, 1989.

[8] A. Bakke, P. Froyen, and L. Skattebol, "Field response to a new pheromonal compound isolated from Ips typographus," Naturwissenschaften, vol. 64, no. 2, pp. 98-99, 1977.

[9] B. S. Lanne, P. Ivarsson, P. Johnsson, G. Bergström, and A. B. Wassgren, "Biosynthesis of 2-methyl-3-buten-2-ol, a pheromone component of Ips typographus (Coleoptera: Scolytidae)," Insect Biochemistry, vol. 19, no. 2, pp. 163-167, 1989.

[10] T. Zhao, A.-K. Borg-Karlson, N. Erbilgin, and P. Krokene, "Host resistance elicited by methyl jasmonate reduces emission of aggregation pheromones by the spruce bark beetle, Ips typographus," Oecologia, vol. 167, no. 3, pp. 691-699, 2011.

[11] H. Giesen, U. Kohnle, J. P. Vité, M.-L. Pan, and W. Francke, "Das Aggregationspheromon des mediterranen Kiefernborkenkäfers Ips (Orthotomicus) erosus," Journal of Applied Entomology, vol. 98, no. 1, pp. 95-97, 1984.

[12] Q. H. Zhang, J. H. Ma, F. Y. Zhao, L. W. Song, and J. H. Sun, "Aggregation pheromone of the qinghai spruce bark beetle, Ips nitidus eggers," Journal of Chemical Ecology, vol. 35, no. 5, pp. 610-617, 2009.

[13] Q. H. Zhang, L. W. Song, J. H. Ma, F. Z. Han, and J. H. Sun, "Aggregation pheromone of a newly described spruce bark beetle, Ips shangrila Cognato and Sun, from China," Chemoecology, vol. 19, no. 4, pp. 203-210, 2009.

[14] D. Klimetzek, J. Bartels, and W. Francke, "Das PheromonSystem des Bunten Ulmenbastkäfers Pteleobius vittatus (F.) (Col., Scolytidae)," Journal of Applied Entomology, vol. 107, no. 5, pp. 518-523, 1989.

[15] E. J. Baader, "Pityogenes spp. (Col., Scolytidae): investigations on semiochemicals and their application in forest protection," Journal of Applied Entomology, vol. 107, no. 1, pp. 1-31, 1989.

[16] M. Zuber, "Racemate and enantiomers of ipsdienol for attracting Ips amitinus (Eichh.) (Col., Scolytidae)," Anzeiger für Schaedlingskunde Pfanzenschutz Unweltschutz, vol. 67, no. 5, pp. 92-93, 1994.

[17] H. J. Veith, N. Koeniger, and U. Maschwitz, "2-methyl-3-butene-2-ol, a major component of the alarm pheromone of the hornet Vespa crabro," Naturwissenschaften, vol. 71, no. 6, pp. 328-329, 1984.
[18] R. Kaiser, The Scent of Orchids, Elsevier, Amsterdam, The Netherlands, 1993.

[19] R. Wohlfart, R. Hansel, and H. Schmidt, "Sedative hypnotic principles in hops. Part 4. Pharmacology of the hop constituent 2-methyl-3-buten-2-ol," Planta Medica, vol. 48, no. 2, pp. 120-123, 1983.

[20] R. Wohlfart, G. Wurm, R. Hansel, and H. Schmidt, "edative hypnotic principles in hops. Part 5. degradation of humulones and lupulones to 2-methyl-3-buten-2-ol, a hop constituent possessing sedative hypnotic activity," Archiv der Pharmazie, vol. 316, no. 2, pp. 132-137, 1983.

[21] G. J. Mannering and J. A. Shoeman, "Murine cytochrome P4503A is induced by 2-methyl-3-buten-2-ol, 3-methyl-1pentyn-3-ol(meparfynol), and tert-amyl alcohol," Xenobiotica, vol. 26, no. 5, pp. 487-493, 1996.

[22] M. Dicke, "Behavioural and community ecology of plants that cry for help," Plant, Cell and Environment, vol. 32, no. 6, pp. 654-665, 2009.

[23] D. McGinty, J. Scognamiglio, C. S. Letizia, and A. M. Api, "Fragrance material review on 2-methyl-3-buten-2-ol," Food and Chemical Toxicology, vol. 48, supplement 3, pp. S97-S100, 2010.

[24] P. Zimmerman, W. Pollack, A. Guenther, and H. Westberg, "Field deployment of a GC-MS system for determination of biogenic hydrocarbons in vegetation enclosures and ambient air (abstract)," Eos Transactions, American Geophysical Union, vol. 72, p. 88, 1991.

[25] P. D. Goldan, W. C. Kuster, F. C. Fehsenfield, and S. A. Montzka, "The observation of a C5 alcohol emission in a north American pine forest," Geophysical Research Letters, vol. 20, no. 11, pp. 1039-1042, 1993.

[26] P. Harley, V. Fridd-Stroud, J. Greenberg, A. Guenther, and P. Vasconcellos, "Emission of 2-methyl-3-buten-2-ol by pines: A potentially large natural source of reactive carbon to the atmosphere," Journal of Geophysical Research D, vol. 103, no. 19, pp. 25479-25486, 1998.

[27] A. M. El-Sayed, V. J. Heppelthwaite, L. M. Manning, A. R. Gibb, and D. M. Suckling, "Volatile constituents of fermented sugar baits and their attraction to Lepidopteran species," Journal of Agricultural and Food Chemistry, vol. 53, no. 4, pp. 953958, 2005.

[28] J. Stökl, A. Strutz, A. Dafni et al., "A deceptive pollination system targeting drosophilids through olfactory mimicry of yeast," Current Biology, vol. 20, no. 20, pp. 1846-1852, 2010.

[29] G. Fantechi, N. R. Jensen, J. Hjorth, and J. Peeters, "Mechanistic study of the atmospheric degradation of isoprene and MBO," in Proceedings of the EUROTRAC symposium, pp. 397340, Computational Mechanics, 1996.

[30] C. Ferronato, J. J. Orlando, and G. S. Tyndall, "Rate and mechanism of the reactions of $\mathrm{OH}$ and $\mathrm{Cl}$ with 2-methyl-3-buten2-ol," Journal of Geophysical Research D, vol. 103, no. 19, pp. 25579-25586, 1998.

[31] D. Grosjean and E. Grosjean, "Carbonyl products of the ozone-unsaturated alcohol reaction," Journal of Geophysical Research, vol. 100, no. 11, pp. 22815-22820, 1995.

[32] E. Grosjean and D. Grosjean, "Rate constants for the gasphase reactions of ozone with unsaturated aliphatic alcohols," International Journal of Chemical Kinetics, vol. 26, no. 12, pp. 1185-1191, 1994.

[33] M. Hallquist, S. Langer, E. Ljungström, and I. Wängberg, "Rates of reaction between the nitrate radical and some unsaturated alcohols," International Journal of Chemical Kinetics, vol. 28, no. 6, pp. 467-474, 1996. 
[34] Y. Rudich, R. Talukdar, J. B. Burkholder, and A. R. Ravishankara, "Reaction of methylbutenol with hydroxyl radical: mechanism and atmospheric implications," Journal of Physical Chemistry, vol. 99, no. 32, pp. 12188-12194, 1995.

[35] A. W. H. Chan, M. M. Galloway, A. J. Kwan et al., "Photooxidation of 2-methyl-3-buten-2-ol (MBO) as a potential source of secondary organic aerosol," Environmental Science and Technology, vol. 43, no. 13, pp. 4647-4652, 2009.

[36] T. M. Fu, D. J. Jacob, F. Wittrock, J. P. Burrows, M. Vrekoussis, and D. K. Henze, "Global budgets of atmospheric glyoxal and methylglyoxal, and implications for formation of secondary organic aerosols," Journal of Geophysical Research D, vol. 113, no. 15, Article ID D15303, 17 pages, 2008.

[37] A. Guenther, T. Karl, P. Harley, C. Wiedinmyer, P. I. Palmer, and C. Geron, "Estimates of global terrestrial isoprene emissions using MEGAN (Model of Emissions of Gases and Aerosols from Nature)," Atmospheric Chemistry and Physics, vol. 6, no. 11, pp. 3181-3210, 2006.

[38] J. C. Dickens, "Behavioral and electrophysiological responses of the bark beetle, Ips typographus, to potential pheromone components," Physiological Entomology, vol. 6, no. 3, pp. 251261, 1981.

[39] F. Schlyter, J. Lofqvist, and J. A. Byers, "Behavioural sequence in the attraction of the bark beetle Ips typographus to pheromone sources," Physiological Entomology, vol. 12, no. 2, pp. 185-196, 1987.

[40] R. A. Werner and E. H. Holsten, "Current status of research with the spruce beetle Dendroctonus rufipennis," in Application of Semiochemicals for Management of Bark Beetle InfestationsProceedings of an Informal Conference USDA For Ser Gen Tech Rep INT-GTR-318, S. M. Salom and K. R. Hobson, Eds., pp. 23-29, 1995.

[41] D. W. Gray, "Field response of Ips paraconfusus, Dendroctonus brevicomis, and their predators to 2-methyl-3-buten-2-ol, a novel alcohol emitted by ponderosa pine," Journal of Chemical Ecology, vol. 28, no. 8, pp. 1583-1597, 2002.

[42] D. W. Gray, S. R. Breneman, L. A. Topper, and T. D. Sharkey, "Biochemical characterization and homology modeling of methylbutenol synthase and implications for understanding hemiterpene synthase evolution in plants," The Journal of Biological Chemistry, vol. 286, no. 23, pp. 20582-20590, 2011.

[43] A. J. Fisher, B. M. Baker, J. P. Greenberg, and R. Fall, "Enzymatic synthesis of methylbutenol from dimethylallyl diphosphate in needles of Pinus sabiniana," Archives of Biochemistry and Biophysics, vol. 383, no. 1, pp. 128-134, 2000. 

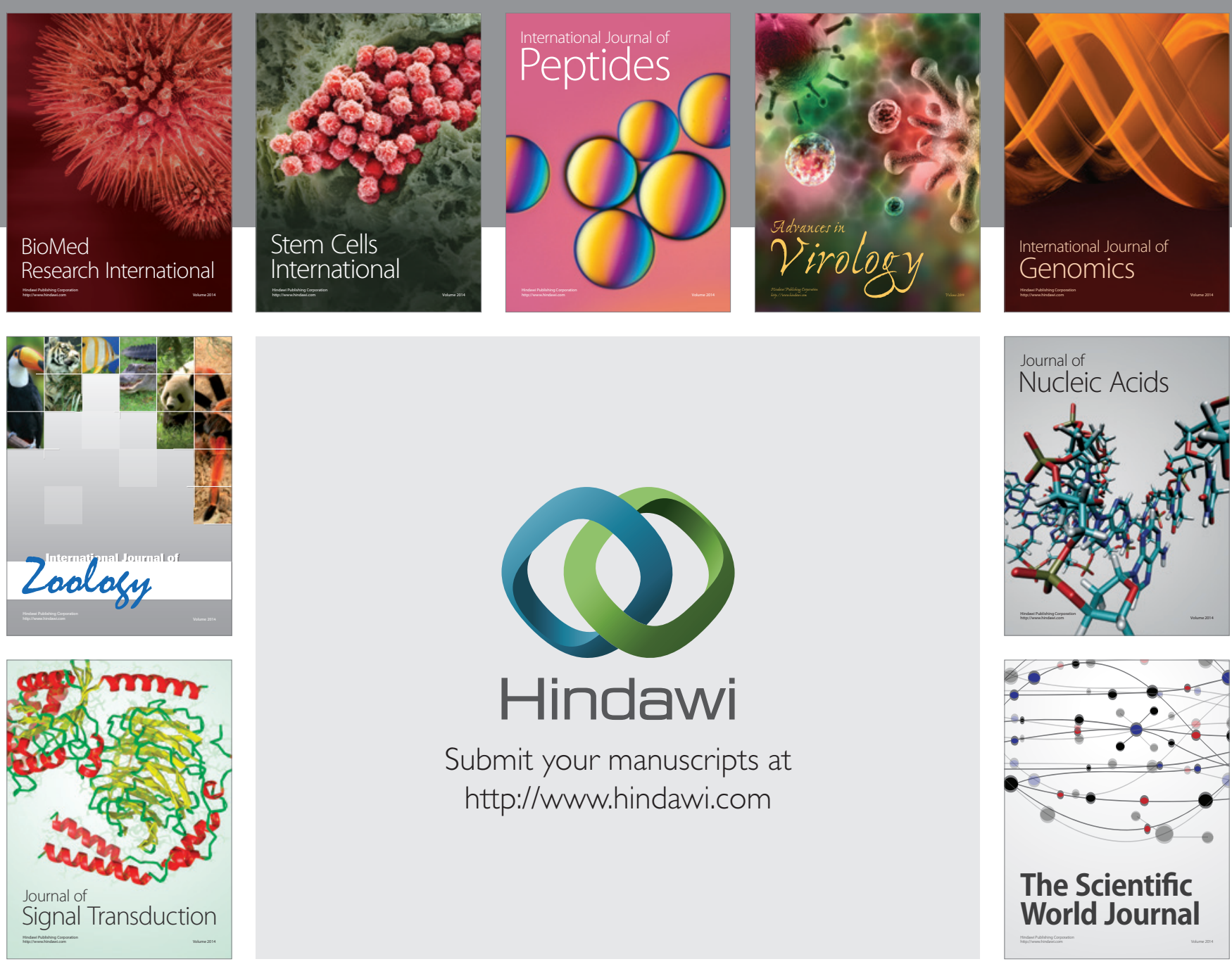

Submit your manuscripts at

http://www.hindawi.com
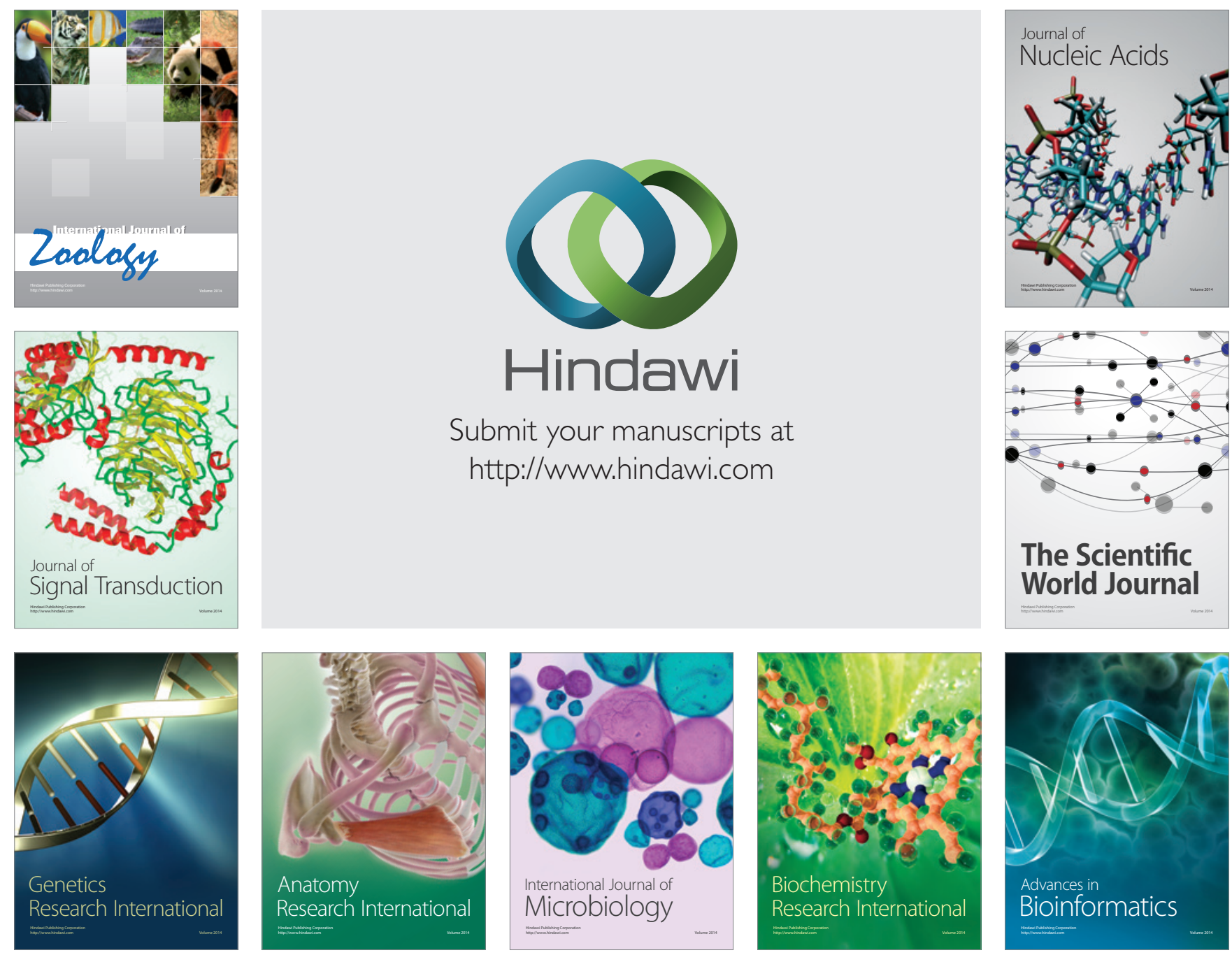

The Scientific World Journal
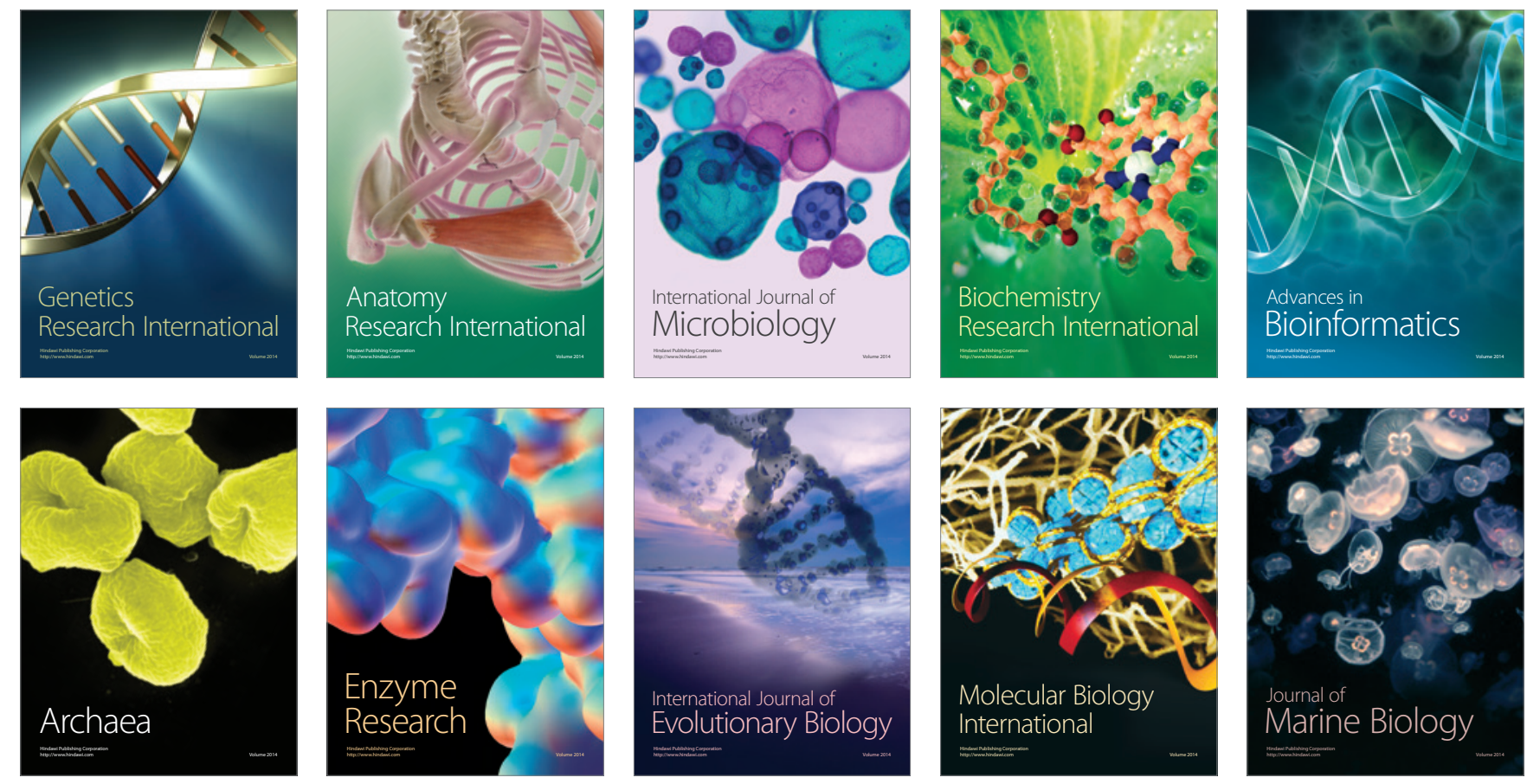